\title{
The Implementation of Character Education in EFL Class
}

\author{
Feny Martina \\ fenymartoina.ms@gmail.com \\ IAIN Bengkulu \\ Sandra Hidayat \\ sandrahidayat44@gmail.com \\ IAIN Bengkulu \\ Ali Akbarjono \\ IAIN Bengkulu \\ Aliakbarj250975@gmail.com
}

\begin{abstract}
This study aims to explore the implementation of character education values based on the five main values of strengthening character education. The method employed in this study was descriptive qualitative. The sample consisted of two English teachers in SMAN 4 Mukomuko. The researcher used 5 main values of character education as the research limitation in conducting this study. The technique of data collection were observation, interview, and documentation. The result of this study shows that teachers in SMAN 4 Mukomuko have implemented the 5 main values in strengthening character education, such as religion, nationalism, integrity, independence, and mutual cooperation value. The teachers show and teach the value of character education in the school well. They have been carried out quite well in the teaching and learning process. Although there were obstacles faced by teachers at SMAN 4 Mukomuko, the school were also constantly looking for solution to overcome the problems by strengthening teachers cooperation and building good relationship between parents of student and SMAN 4 Mukomuko.
\end{abstract}

Keywords: Character Education-Exploring-Teacher

\section{A. Introduction}

Character education is a conscious effort to instill and develop good values in the framework of humanizing humans, to improve character and train students' intellectuals, so as to create a generation of knowledge and character that can benefit the surrounding environment. Strengthening moral education or character education in the current context is very relevant to overcome the moral crisis that is happening in our country. Character education is also actually an education that is emphasized in education in Indonesia today. According to Presidential Regulation Number 87, 2017 about Strengthening Character Education (2017), "PPK is implemented by applying Pancasila values in character education, especially covering the values of religious, honesty, tolerant, discipline, hard work, creative, independent, democratic, curiosity, national spirit, love for the country, 
respect for achievement, communicative, peace-loving, fond of reading, care for the environment, social care, and to be responsible.". The Presidential Regulation on Strengthening Character Education above stated that character education must apply values of Religion, honesty, tolerance, discipline, hard work, creative, Independence, democratic, curiosity, national spirit, love of the motherland, respect for achievement, communicative, peace-loving, fond of reading, caring for the environment, caring socially, responsible, and applying the values contained in Pancasila. Those character education could be in the lesson plan of the teacher (Apriani, et al. 2020). Besides, character education could be implemented by teacher to students to strengthen their character in learning and support the pedagogical competence (Martina, et al. 2020).

The phenomena in the field today, there are still students who do not show good character and less moral. As reported by detik.com (2019) that the incident that spread in social media some time ago where a high school student in Gresik challenged the teacher because the teacher reprimanded and advised the student was smoking. This shows that the student has less moral. Seeing this incident, we need to pay attention to how character education is in the education curriculum in Indonesia today. The most recent case of other high school students showing students who have no character and no morals is the brawl between high school students in Depok city, in January 2020. The incident disturbed the public, because the brawl also came into the mall. Of course this does not reflect a good character value and it also showed that the students did not have and applied the value of character education.

There are some related previous study conducted some research about character education, and the the researcher chooses some literature. From various previous studies on character education above, that previous studies have discussed many aspects of character education. Research conducted by researcher will certainly be different from others. This research focused on exploring the 5 main values of strengthening character education as conveyed by the ministry of education and culture. Then, this research also focused on the process of implant (teaching and learning) character education in the classroom that is focused on English classes. And of course this research is conducted to explore whether the school has had good character education or not, so that it can help teachers and students to improve character education, and it can be a reference for parents to choose schools for their children. 
The researcher did preliminary in SMAN 4 Mukomuko. the researcher found some information about the problem related to the student character education as follows; a) Student fight each other, b) Students use local language when asking and answering teacher questions in class room, c) Students talk to his friend when the teacher explains the lesson in the class room, d) Students cheat their friends' assignments, e) Students do not come to school on time, f) Student annoys other student, g) Students cheat when taking exams.

This study aims (a) to know the Religion, Nationalism, Integrity, Independence, and Mutual Cooperation values of character education implemented in SMAN 4 Mukomuko in academic year 2020/2021, (b) to know the obstacles that faced by English teacher in implementing and teaching of five main values of character education in EFL Class at $11^{\text {th }}$ Grade SMAN Mukomuko.

\section{B. Research Methodology}

In exploring the implementation of character education in SMAN 4 Mukomuko, the approach of this research that used by the researcher was qualitative. The qualitative approach chosen in this study was based on the problems that would be studied and explored by the researcher, namely the implementation of character education as a hidden curriculum in the 2013 curriculum. In accordance with the understanding of qualitative research according to Sukmadinata (2010 : 50) states Qualitative research is inductive, researchers allow problems to arise from data or left open for interpretation. Data were collected by careful observation, including descriptions in detailed contexts accompanied by notes from the results of in-depth interviews, as well as the results of analysis of documents and records. As the purpose of this study, qualitative research has two main objectives, namely: 1) describe and express (to describe and explore) and 2) describe and explain (to describe and explain). Based on the objectives to be achieved, qualitative research uses data collection instruments that suit their objectives. In this research, the researcher used design of descriptive method which is a method of research that attempt to describe and interpret the objects in accordance with reality. The descriptive method is implemented because the data analysis is presented descriptively. The statement above is in accordance with the opinion of Bogdan and Taylor in Moleong "Metode descriptive merupakan prosedur penelitian yang menghasilkan data deskriptif berupa kata-kata tertulis atau lisan dari orang-orang dan perilaku yang dapat diamati.". The statement 
above shows that the descriptive method is a research procedure that produces descriptive data in the form of written or oral from people and observable behavior. Descriptive method was chosen because the researcher will collect descriptive data which is mostly written in the form of reports and descriptions and it does not prioritize statistical figures even though it does not reject quantitative data. The location of this research was SMAN 4 Mukomuko. This school was chosen by the researcher because of the accessibility and availability of time. The subject of this research were the English teachers and $11^{\text {th }}$ grade students SMAN 4 Mukomuko in academic year 2020/2021. To get the data in this research, the researcher was going to take data through some sources, the subject of research were student and teacher interactions, process of teaching and learning, materials, the notes taken by the interview, and documentation. In other words the data sources of this study were all elements of teaching learning process committed by teacher, the students, the assistant of principal, SMAN 4 Mukomuko, and counseling and guidance teacher. In collecting the data, researcher used observation, interview, and documentation study technique. There are guidelines for interview, 20 observation checklist, and audio recorder as the instruments to help the researcher conducted the research. The data obtained from the results of observations, interviews, and documentation studies are then processed through recording, typing, and editing then analyzed qualitatively.

\section{Results and Discussion}

\section{Result}

The explanation of the result is divided into some parts. The following findings would give detail description about (1) The implementation the Religion, Nationalism, Integrity, Independence, and Mutual Cooperation values of character education in SMAN 04 Mukomuko in academic year 2020/2021, (2) The obstacles that faced by English teacher in implementing and teaching of five main values of character education in EFL Class at $11^{\text {th }}$ Grade SMAN Mukomuko.

In terms of religion, the subject observed was an English teacher in teaching and learning process in $11^{\text {th }}$ grade. There were some findings that the researcher figured out, based on the result of observation conducted on August $3^{\text {rd }} 2020$. First, aspect of tolerance. Before the class started, teacher asked the students to pray according to their respective beliefs and religions, without any intimidation or prohibition, because in the class there were several non-Moslem students (2020 : 
Observation). The teacher also gave the same respect to all students without any discrimination. Second finding was the sincere aspect. In the process teaching and learning, teacher explained back when students had not understood the lesson. It also showed unselfishness as one of the aspects Religion. This showed that the understanding was more important than speed in learning. Next finding was fond of worship. Before finished the class, the teacher did not forget to remind the students to do the midday prayer at Mushola. When the researcher conducted observation on August $7^{\text {th }} 2020$, the researcher got routine activities at this school. Every Friday before starting lessons, students must read Al Quran and its meaning every morning together (2020 : Observation). That activity taught students to love the holy Qur'an as one of the aspects in Religion value. Assistant principal of academic affairs and curriculum stated that SMAN 4 Mukomuko has good Religion values. She said that: "In terms of Religion values, teachers always invite students to always pray in congregation at the school prayer room, and students follow what their teacher says, and some even carry out the Sunnah Duha prayer Independently."

In terms of nationalism, there were some findings that the researcher found. Based on the result of observation conducted on August $4^{\text {th }} 2020$, the researcher got this school had good nationalism values (2020 : Observation). First, even though students in the class had different ethnicities and religions, there was no discrimination by the teacher in the learning process. The teachers provided equal and same opportunities to all students. It showed that the aspect of mutual respect was implemented. Second findings was maintaining the nation's culture. When explaining the subject matter, the teacher also used examples that referred to regional and Indonesian cultural values. Even the teacher gave an example for students to throw garbage in the trash as an implementation of the aspect of protecting the environment in nationalism value. In terms of the value of nationalism according to the limits of this study, the teachers at this school had implemented the value of strengthening character education. The result of observation above were in line with the statement of assistant principal of academic affairs and curriculum stated that SMAN 4 Mukomuko. She said that:

"The school always invite students to love our nation. For example, the teacher give examples related to Indonesian culture in classroom. In addition, this school always invites students to commemorate Indonesian heroes' days such as parades and drama performances (2020 : Interview)" 
In terms of integrity, SMAN 4 Mukomuko had good integrity (2020 : Obsevartion). Based on observation conducted on August $4{ }^{\text {rd }} 2020$, the researcher got some findings. The first aspect of integrity was trustful. The teacher arrived on time at school, especially come to class for teaching in the classroom. Second findings was commitment. The teacher showed good commitment in teaching and learning process by continuing to explain the material until the students understood the lesson. The teacher also provided the opportunity for all students to ask questions and answer without discriminating of ethnicity and religion. It meant that, teacher gave same opportunity for all students. In other words, it described the fair aspect. When conducted observation, the researcher also got information that when condition were normal before Covid-19, every morning the students took out the trash together. Due to current conditions, these activities were not carried out to avoid crowds in the school.

The researcher also found the values of independence when conducted observation on August $6^{\text {th }} 2020$ in SMAN 4 Mukomuko. The researcher got some findings in the learning and teaching process (2020 : Observation). First finding was professionalism. In doing assignments, teacher prohibited students from cheating on their friends except for group work. Absolutely it taught the students to be Independence indirectly. Second findings was brave aspect. In the learning and teaching process, teachers also conveyed wrongs and truths according to facts . In explaining material, the teacher also used media and interesting lesson examples so that students could understand and do assigned tasks independently. It indicated that the teacher was creative.

The next finding was taken from interview. Assistant principal of academic affairs and curriculum explained that teachers always asked students to do assignments or homework independently without cheating on friends.

SMAN 4 Mukomuko had good values of mutual cooperation or "Gotong Royong" (2020 : Observation). This could be seen from several findings when the researcher conducted observation on August $6^{\text {th }}$ 2020. First finding was inclusivity. Teacher asked for other students to help students who were less able to understand the lesson. The teacher also made a study team so that students could help each other and exchange ideas. The second finding was teacher also provided opportunities for 
students to re-explain the material to other students in different ways, so that other students understood the lesson better.

There were several obstacles faced by the teachers and school in implementation character education in teaching and learning process. The first obstacle was the influence of friends. Classmates have a strong influence on other students, plus if they were students in the same village, they felt like the majority had a little bit of pride and a sense of domination in the arts. Apart from the influence of the environment, especially social media, SMAN 4 Mukomuko still lacked an icon to be an example for students, because there were still some teachers who emphasized the academic side and sometimes forgot a little about character values. Although there were obstacles faced by teachers at SMAN 4 Mukomuko, the schools were also constantly looking for solution to overcome them problems in teaching and implementing the values of five main values of character education. The assistant principal of academic affairs and curriculum stated that every teacher had to increase the value of character education for students, not only intellectually

\section{Discussion}

After the researcher collected data from research results obtained from observations, interviews, and documentation, the researcher conducted data analysis to further explain the research results. In accordance with the data analysis technique chosen by researcher, namely by using descriptive qualitative analysis by analyzing data that collected during the study conducted research at SMA Negeri 4 Mukomuko. Based on the results of the study, researcher obtained information as follows:

In implementation of five main values of character education in EFL class at $11^{\text {th }}$ grade SMAN 4 Mukomuko. The results showed the teacher fulfilled several aspects and indicators of implementation the value of strengthening character education in the classroom. This effort was also encouraged by the vice principal of the curriculum field so that every teacher must be a good icon to the students. When students saw firsthand the phenomena that occur in the surrounding environment. Real experiences obtained by students will help student in developing self-potential and applying the value of strengthening character education. 
The findings also showed that SMAN 4 Mukomuko has implemented five main values of strengthening character education as the hidden curriculum of 2013 curriculum. In learning and teaching process, the teacher showed good example regarding the value of strengthening character education. However, the cooperation between the school and the parents must be improved so that the cultivation of the value of character education can be maximized. In addition, SMAN 4 Mukomuko still needed many icons that provide examples in the application and teaching of character education values. This finding is in line with Maimunah (2015) who also found that the school had implemented character education.

In implementation values of strengthening character education, of course there were obstacles faced by teachers. In the case of strengthening character education, there were several obstacles that must be faced. The first obstacle was the influence of friends. Classmates had a strong influence on other students, if students had a desk mate, they felt like the majority have a little pride and a sense of domination in the classroom. The second obstacle was the lack of icons to serve as examples for students, because there were still some teachers who emphasized the academic side and sometimes forgot a little about character values.

In dealing with the problems of implementation character education, the school would take several steps as a solution to overcome obstacles and problems in improving character education, namely by evaluating teachers who taught in the class to provide examples or good attitudes to students, so that there was continuity and cohesiveness of teachers in the classroom. The second solution was build good relationship and coordination. In this case the teacher would build a good relationship with the parents of students. So that teachers and parents could coordinate with each other regarding the attitudes of students.

Based on the findings in this study, the researcher found the similarities with previous study or previous research about "CHARACTER EDUCATION IN EFL CLASS (A Descriptive Study at the Fourth Grade of SDN Sadeng 02 Gunungpati Semarang by Fadilah (2016). The purpose of this study was to determine how character education affected the behavior of students. In the previous study, the researcher found data that character education has a good impact on the behavior of students at SDN Sadeng 02 Gunungpati Semarang. This was also a discovery by the researcher at SMAN 4 Mukomuko. The researcher found 5 values of strengthening 
character education at SMAN 4 Mukomuko have been implemented properly by the teacher, and it has a good effect toward the students.

\section{Conclusion and Suggestion}

Based on the results of research conducted by researcher in SMAN 4 Mukomuko, the researcher made the following conclusions, namely: (1) SMAN 4 Mukomuko has used the 2013 curriculum and has implemented the 5 main values of strengthening character education. The implementation of religion, nationalism, integrity, independence, and mutual cooperation value in the teaching and learning process has been carried out quite well.; (2) Obstacles in implementation of strengthening character education at SMAN 4 Mukomuko is divided into two obstacles. The first obstacle is the influence of friends. Classmates have a strong influence on other students. If they are students from same village, they felt like as the majority have a little bit of pride and a sense of domination in the classroom, so that there was a sense of arrogance and sometimes the student did not give attention to the teacher. The second obstacle is lack of icon to be an example for students, because there were still some teachers who emphasize the academic side and sometimes forget a little about character values. Although there were obstacles faced by teachers at SMAN 4 Mukomuko, the schools were also constantly looking for solution to overcome them problems in teaching and implementing the values of five main values of character education by strengthening teachers cooperation and building good relationship between parents of student and SMAN 4 Mukomuko.

Based on the above conclusions, the suggestions that can be given are as follows:

1. English teacher should continue to understand more about character education especially five main values in strengthening character education being applied. This is because school has to integrate intellectual and character education values. In addition, teacher is expected to attend trainings, teaching simulations related to the character education.

2. Schools must equalize the perspectives of all teachers at SMAN 4 Mukomuko to build the same goal of increasing the intellectual and character of students, and building good relationships with parents of students, so that they can monitor the character of students in their action. 
3. For further researcher who wish to examine about implementation character education, it is recommended to examine character education as a whole and which are not included in this study.

\section{References}

Apriani, E., Supardan, D., Syafryadin., Noermanzah., Umami, M. (2020). Independent Learning: English Teachers' Problems in Designing a Good Lesson Plan in New Normal Era at MAN Rejang Lebong. International Conference on the Teaching English and Literature. 1(1), 72-78.

Arthur, J. (2003). Education with Character, The moral economy of schooling, (London and New York : Routledge Falmer Taylor \& Francis Group.

Bachri., B.S. (2010). Meyakinkan Validitas Data Melalui Triangulasi Pada Penelitian Kualitatif. Kurikulum dan Teknologi Pendidikan, Fakultas Ilmu Pendidikan Universitas Negeri Surabaya. Jurnal Teknologi Pendidikan, 10(1), 1.

Brown H. D. (2004). Principles of Language and Teaching $4^{\text {th }}$ Ed. England: Pearson Education.

Citra, Y.. 2012. Pelaksanaan Pendidikan Karakter Dalam Pembelajaran. E-JUPEKhu (Jurnal Ilmiah Pendidikan Khusus). Volume 1 Nomor 1 Januari 2012. http://ejournal.unp.ac.id/index.php/jupekhu

Data Pokok Pendidikan. (2020). Data Pokok Sekolah. SMAN 4 Mukomuko. Retrived from https://dapo.kemdikbud.go.id/.

Enamul, H. (2016) Three Domains of Learning: Cognitive, Affective and Psychomotor. The Journal of EFL Education and Research (JEFLER) : Dhaka, Bangladesh

Fadlilah, F.N. (2016). Character Education in Efl Class (A Descriptive Study at the Fourth Grade of SDN Sadeng 02 Gunungpati Semarang in the Academic Year of 2013/2014)". A Thesis of Walisongo State Islamic University. Jawa Tengah.

Gregory, P. (2017). Learn English. Delhi:Global Media Education.

Harahap, A. (2018) Implementasi Nilai-Nilai Karakter Dalam Pembelajaran Tematik Kelas III SDIT Darul Hasan Padangsidempuan. Jurnal Pendidikan Madrasah Ibtidaiyah,

Haris, Counseling Guidance Teacher at SMAN 4 Mukomuko, interviewed on August $10^{\text {th }}$ 2020, at 13.00 p.m

H. Hasanah, I G Nurjaya, \& M Astika. (2017). Pengintegrasian Sikap Spiritual dan Sikap Sosial dalam Pembelajaran Teks Ulasan Film/Drama di Kelas XIMIPA SMA Negeri 3 Singaraja. E-Jurnal Jurusan Pendidikan Bahasa dan Sastra Indonesia. Undiksha : Singaraja.

Harmer, J. (2001) The Practice of English Language Teaching, (London: Pearson Education).

Kadir, A. (2004) Dasar-dasar Pendidikan. Jakarta: Kencana, 1(1) : Universitas

Muhammadiyah Tapanuli Selatan

Kementerian Pendidikan dan Kebudayaan. (2017). Penguatan Pendidikan Karakter Jadi Pintu Masuk Pembenahan Pendidikan Nasional 2017. Retrieved from https://www.kemdikbud.go.id/main/blog/2017/07/penguatan-pendidikan-karakterjadi-pintu-masuk-pembenahan-pendidikan-nasional

Lembaran Negara Republik Indonesia. Peraturan Presiden Republik Indonesia Nomor 87 Tahun 2017. Penguatan Pendidikan Karakter.:Jakarta.pdf

Lexy J Moleong. Metodologi Penelitian Kualitatif. Bandung: PT Remaja Rosdakarya

Lusiana, (2020). Vice principal of SMAN 4 Mukomuko, interviewed on August $10^{\text {th }} 2020$, at 10.30 a.m 
Marvin W. Berkowitz, (2011). The Science of Character Education. (Damon: Hoover Press,2011), pdf.

Martina, F., Syafryadin, J. S., \& Rakhmanina, L. (2020). Novice teacher's pedagogical content knowledge (PCK) in teaching English for young learners. Journal of Critical Reviews, 7(14), 1472-1476.

Maunah, B. (2015). Implementasi Pendidikan Karakter Dalam Pembentukan Kepribadian Holistik Siswa. Jurnal Pendidikan Karakter, Nomor 1, Tahun 2015. https://journal.uny.ac.id

Nurhalim, M. (2014). Optimalisasi Kurikulum Aktual Dan Kurikulum Tersembunyi Dalam Kurikulum 2013. Education Jurnal. Insania, Vol. 19, No. 1

Nucci, Larry \& Narvaez, D. (2008). Handbook Moral and Character Education. Rouletgde: UK. Pdf

Patricia., Zahirah., Salahuddin (2011). Character Education in a Muslim School : A Case Study at a Comprehensive Muslim School's Curricula, Thesis (Miami, Florida: Florida International University

Qoriah, H. (2012). Peranan Pendidikan Kewarganegaraan Dalam Membangun Moral Anak Tunarungu Di Sekolah Luar Biasa Negeri Cileunyi. Universitas Pendidikan Indonesia. pdf

Samsudhuha WIldansyah. Detik News. (2020). Viral Sekelompok Pelajar SMA di Depok Tawuran hingga Masuk Mal. Retrieved from https://news.detik.com/berita/d4857325/viral-sekelompok-pelajar-sma-di-depok-tawuran-hingga-masuk-mal.

Sani, I.M. \& Aan Hasanah . (2019). Penguatan Pendidikan Karakter Peduli Sesama Melalui Kegiatan Ekstrakurikuler Relawan. DOI : 10.14421/jpai.2019.161-06 http://ejournal.uin-suka.ac.id/

Utami, S. (2019). Penerapan Pendidikan Karakter Melalui Kegiatan Kedisiplinan Siswa. Jurnal Pendidikan. Universitas PGRI Semarang Volume 04 Nomor 01 Tahun 2019. e-ISSN: 2527-6891.DOI : 10.26740/jp.v1n1.

Sholeh Hidayat, (2013), Pengembangan Kurikulum Baru, Bandung: PT Remaja Rosdakarya, retrieved from http://repository.uinsu.ac.id/4650/4/BAB\%20II.pdf

Sofian M, Muhammad J, \& Zulella MS. (2018). Implementasi Pendidikan Karakter. Jakad Publishing : Surabaya

Suki. DetikNews. (2019). Kisah Bocah SMP di Gresik Tantang Guru Hingga Bersujud Minta Maaf. Retrieved from https://news.detik.com/berita-jawa-timur/d4422329/kisah-bocah-smp-di-gresik-tantang-guru-hingga-bersujud-minta-maaf

Wikipedia.com. (2020) Kurikulum 2013. Retrieved from https://id.wikipedia.org/wiki/ Kurikulum_2013

Yusnita, A. (2013). Model Pembinaan Akhlak di SMAN 20 Bandung. Universtitas Pendidikan Indonesia. repository.upi.edu.pdf.

Yeni, F. (2020). English Teacher of SMAN 4 Mukomuko, Interviewed on March $23^{\text {rd }} 2020$, 09.30 a.m

Zubaedi, (2015). Desain Pendidikan Karakter: Konsepsi dan Aplikasinya dalam Lembaga Pendidikan. Jakarta: Kencana. 